the lateral gradient of attention. In: Rabbitt PMA, Dornic $\mathrm{S}$, eds. Attention and performance. London: Academic Press, 1975.

18 Kinsbourne $M$. Mechanisms of unilateral neglect. In: Jeannerod M, ed. Neurophysiological and neuropsychological aspects of spatial neglect. Amsterdam: Elsevier, 1987:69-86.

19 De Renzi E, Faglioni P, Scotti G. Hemispheric contribution to the exploration of space through the visual and tactile modality. Cortex 1970;6:191-203.

20 Chèdru $F$, Leblanc $M$, Lhermitte $F$. Visual searching in normal and brain-damaged subjects (contribution to the study of unilateral inattention). Cortex 1973;9:94-111.

21 Mesulam M. Attention, confusional states and neglect. In: Mesulam MM, ed. Principles of behavioral neurology. Philadelphia: FA Davis, 1985.

22 Riddoch MJ, Humphreys GW. Perceptual and action systems in unilateral visual neglect. In: Jeannerod $M$, ed.
Neurophysiological and neuropsychological aspects of spatial neglect. Amsterdam: Elsevier, 1987:151-81.

23 Gainotti G D'Erme P, De Bonis C Visual attention disrupted in unilateral neglect. in: Brown JW, ed. Neuropsychology of Visual Perception, Hillsdale. New Jersey: Lawrence Erlbaum, 1989

24 Colombo A, De Renzi E, Faglioni P. The occurrence of visual neglect in patients with unilateral cerebral disease. Cortex 1986;12:221-31.

25 Seron X, Deloche G, Coyette F. A retrospective analysis of a single case neglect therapy: a point of theory. In: Seron X, Deloche $\mathrm{G}$, eds. Cognitive approach to neuropsychological rehabilitation, Hillsdale, New Jersey: Lawrence Erlbaum, 1989.

26 Weinberg J, Diller L, Gordon A, et al. Training sensory awareness and spatial organization in people with brain damage. Archives of Physical Medicine and Rehabilitation 1979;60:491-6.

\title{
DEPICTIONS OF AN ODYSSEY
}

\section{Depictions of an odyssey}

\section{by Peter MacKarell.}

Edited by Sheila Paine.

Published by NSEAD, Corsham, Wiltshire.

On the walls of a top floor at Guy's Hospital, London, are a series of small gouache paintings. Visitors and hospital staff are captivated by the colourful works which painfully illustrate the impact of optic neuritis on an artist's perception of light and form. This book is a posthumous and touching tribute to the painter and patient, Peter MacKarell.

In 1980 Peter MacKarell experienced the onset of multiple sclerosis to which he succumbed eight years later. The artist's struggle with his illness, his fortitude and persistently enquiring nature are described in various ways in the book. It is well written, but the text is eclipsed by MacKarell's paintings.

The foreword is by Richard Hoggart who was warden of Goldsmith's College where the artist was a teacher. It is a warm and generous introduction which describes the artist's "incarceration" in various hospitals, each of which affected the artist's creativity. For example, gloom and despair characterised a period in a ward for the young and chronically disabled. The first chapter by the writer Bevis Hillier covers the artist's career as an illustrator and cartoonist. The second is by a fellow painter, Stanislav Frenkiel, who movingly describes the changing styles, techniques and subjects of the painter as his circumstances and vision alter with the illness.

The last two chapters are by the artist himself. He writes about the optic neuritis which heralded the onset of his disease. He describes the puzzling circumstances of deteriorating vision, blindness and recovery. His series of highly personal pictures illustrate this experience. A later sequence of pictures painted during convalescence now hang in the Institute of Ophthalmology.

The last chapter contains some excerpts from an illustrated journal he kept for his daughter whilst he was in a nursing home. His decline is all too apparent. In the closing pages he struggles to make sense of the confused images of

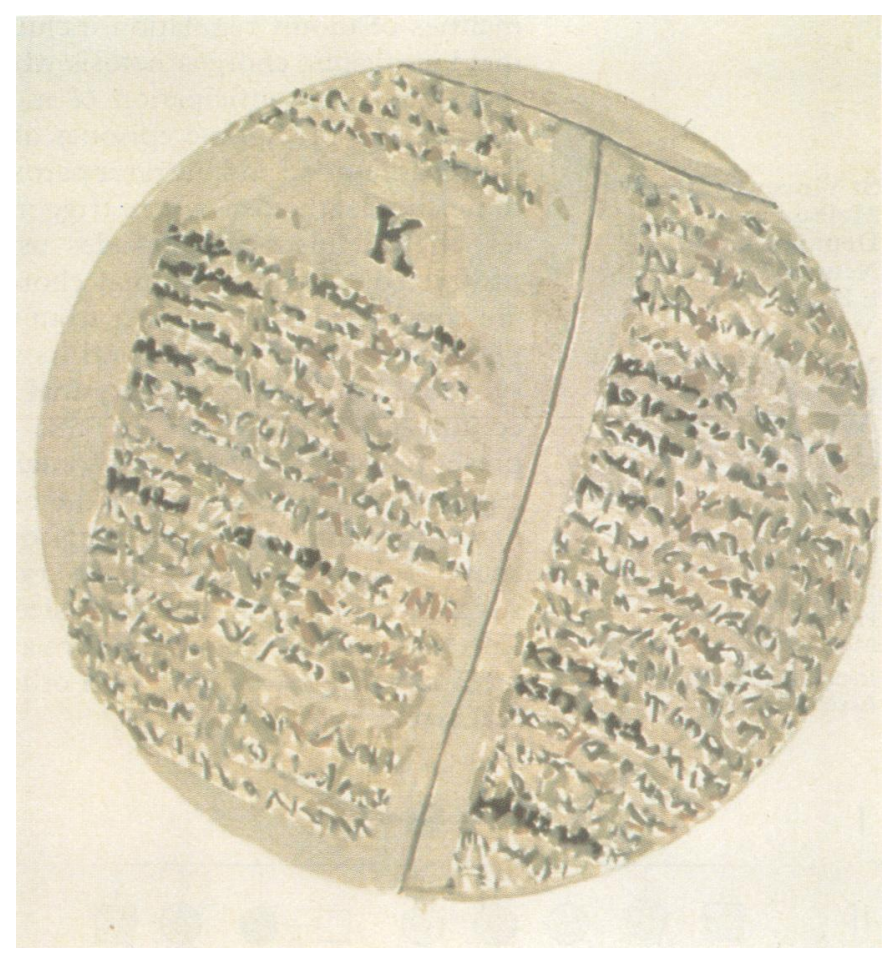

Pageswim. "One evening my lad asked me to look up a word in the French dictionary and I found that I could not make out the print because at each point I attempted to focus, the individual letters were obscured by an infuriating and irritating bouncing grey dot. Although I was a larmed I was somewhat relieved to find I was able to watch the television pictures on the News at Ten. Somewhat shaken by these events I went to bed." (From Depictions of an Odyssey, Peter MacKarell 1990, National Society for Education in Art and Design.)

shape and colour, analysing them with an artist's training, and reflecting fondly on earlier painters who had influenced him.

Peter MacKarell was a supremely talented artist who must have been a great inspiration to his family and friends.

T GIBSON 